\title{
CA6-based macroporous refractory thermal insulators containing mineralizing agents
}

\author{
Borges, O.H. ${ }^{(1,2, *)}$; Santos Jr, T. ${ }^{(1,2)}$; Salvini, V. R. ${ }^{(3)}$; Pandolfelli, V.C. ${ }^{(1,2)}$ \\ (1) Federal University of Sao Carlos, Graduate Program in Materials Science and Engineering. \\ (2) Materials Microstructure Engineering Group (GEMM), FIRE Associate Laboratory, Federal \\ University of São Carlos, Materials Engineering Department, Rodovia Washington Luis, km 235, \\ São Carlos, SP, 13565-905, Brazil. \\ (3) College of Technology (FATEC), Jordão Borghetti Street 480, Sertãozinho, SP, 14160-050, Brazil \\ *Corresponding author at: +55-16-33518253; fax: +55-16-33615404. \\ E-mail: otavio.borges@dema.ufscar.br
}

\begin{abstract}
Aiming at reducing the temperature of $\mathrm{CaO} 6 \mathrm{Al}_{2} \mathrm{O}_{3}\left(\mathrm{CA}_{6}\right)$ formation, $\mathrm{SiO}_{2}, \mathrm{ZnO}$, and $\mathrm{TiO}_{2}$ were evaluated as mineralizing agents in an $\mathrm{Al}_{2} \mathrm{O}_{3}-\mathrm{CaCO}_{3}$ based macroporous thermal insulator. For the concentrations tested $(0.6 \mathrm{~mol} \%$ to $2.8 \mathrm{~mol} \%), \mathrm{SiO}_{2}$ presented a small effect in the temperature of $\mathrm{CA}_{6}$ formation. However, $\mathrm{ZnO}$ and $\mathrm{TiO}_{2}$ favoured full $\mathrm{CA}_{6}$ generation at $1400^{\circ} \mathrm{C}, 200^{\circ} \mathrm{C}$ below the reference composition. All analysed systems, besides $2.8 \mathrm{Si}$, showed high porosity (>80\%), suitable mechanical strength and expansion after firing at $1600^{\circ} \mathrm{C}$ for $5 \mathrm{~h}$. Softening temperature evaluation highlighted that $\mathrm{ZnO}$ - and $\mathrm{TiO}_{2}$-containing compositions could be used at higher temperatures than the $\mathrm{SiO}_{2}$ ones. Thus, compositions containing $2.8 \mathrm{~mol} \%$ of $\mathrm{ZnO}$ or $\mathrm{TiO}_{2}$ were evaluated according to their thermal conductivity ( $\mathrm{k}_{\mathrm{eff}}$ ), showing lower $\mathrm{k}_{\mathrm{eff}}$ than the reference composition. Therefore, using these mineralizing agents, which are easily available, may provide reductions in the energy input to produce $\mathrm{CA}_{6}$-containing thermal insulators and benefits to all other required properties.
\end{abstract}

Keywords: Macroporous refractory, Thermal insulators, Hibonite, Mineralizing agents.

DOI: 10.1016/j.jeurceramsoc.2020.07.011 


\section{Introduction}

Since mankind mastered the use of fire-making Earth, about one million years ago [1], energy became closely linked to technology developments. Illustrating this relationship, data from the United States Energy Information Administration (EIA) show that an average citizen from North America or the Nordic countries spent close to 300 GJ of energy in 2017, while in South America an average person used less than one-fourth of that [2]. Considering that the global economy is forecast to grow by $3 \%$ per year until 2050 [3] and economic prosperity leads to life quality enhancement, we will face a future of high power requirements. In fact, according to the International Energy Agency, the global energy demand will rise by $25 \%$ until 2040 [4]. Therefore, the easiest pathway to supply such growing requirements, ensuring energy security and environmental protection, is by increasing energy efficiency.

Accounting for $37 \%$ of all power consumed in the world in 2018 , industries play a key role when energy issues are under discussion [4], particularly those that operate high-temperature processes. In this scenario, macroporous refractory ceramics have been drawing attention as they can be used as thermal insulators, reducing the amount of energy spent and decreasing production costs. However, to replace the commonly used fiberbased insulators (which can be highly toxic when inhaled and present a shorter working life span) for macroporous materials, some challenges should be overcome. Among them, controlling shrinkage after firing, the reduction of thermal conductivity and the decrease in the energy input required to manufacture this type of material can be cited.

Previous research by the authors of the present paper on macroporous refractories produced by direct foaming and comprised by in situ formed calcium hexaluminate 
$\left(\mathrm{CaAl}_{12} \mathrm{O}_{19}\right.$ or $\left.\mathrm{CA}_{6}\right)$ by the reaction of $\mathrm{Al}_{2} \mathrm{O}_{3}$ and $\mathrm{CaCO}_{3}$, resulted in the development of a macroporous insulator that can be thermally treated at lower temperatures [5], presents low effective thermal conductivity ( $\mathrm{k}_{\mathrm{eff}}$ ) [6] and undergoes volumetric expansion after firing at $1600^{\circ} \mathrm{C}$ for $5 \mathrm{~h} \mathrm{[6].} \mathrm{However,} \mathrm{because} \mathrm{the} \mathrm{two} \mathrm{latter} \mathrm{rely} \mathrm{on} \mathrm{CA}_{6}$ formation, which was fully carried out after firing at $1600^{\circ} \mathrm{C}$, these 3 features could not be attained simultaneously.

A way to circumvent this issue is by reducing the temperature of $\mathrm{CA}_{6}$ formation, which could be achieved by adding mineralizing agents (MA) [7]. However, MA for CA6 reported in the literature are usually transition metal oxides, which can react forming a liquid phase at lower temperatures, decreasing the refractoriness of the material. In this study, $\mathrm{SiO}_{2}, \mathrm{TiO}_{2}$, and $\mathrm{ZnO}$ were evaluated as mineralizing agents for $\mathrm{CA}_{6}$, as previously suggested by Cinibulk [7]. Its effects on refractoriness, mechanical resistance, porosity, thermal conductivity, shrinkage after firing, and $\mathrm{CA}_{6}$ content as a function of the firing temperature were investigated and are discussed below.

\section{Materials and methods}

\subsection{Materials}

Macroporous samples containing the precise ratio of $\mathrm{Al}^{3+}$ and $\mathrm{Ca}^{2+}$ to enable complete $\mathrm{CA}_{6}$ formation after thermal treatment were produced by the direct foaming method following the steps described in [6], using a standard composition (see Table 1). Firstly, an aqueous ceramic suspension comprised by aluminas CL370 ( $\mathrm{D}_{50}=2.5 \mu \mathrm{m}$ ) and A1000SG $\left(\mathrm{D}_{50}=0.6 \mu \mathrm{m}\right)$ - both by Almatis, Ludwigshaften, Germany -, calcium carbonate (Imerys, Doresópolis, Brazil, $99 \%$ purity, $\mathrm{D}_{10}=1.49 \mu \mathrm{m}, \mathrm{D}_{50}=7.38 \mu \mathrm{m}, \mathrm{D}_{90}=$ 
$12.64 \mu \mathrm{m})$, calcium aluminate cement (Secar® 71, Imerys, Le Teil, France), and the organic additives Castament ${ }^{\circledR}$ FS 60, and Lutensol® AT 50 Pulver (both by BASF, Ludwigshafen, Germany) was produced by mechanical stirring. Following, an organic foam also prepared by mechanical stirring a commercial liquid surfactant based on 1,2benzisothiazol-3(2H)-one (Vinapor® GYP 2680, BASF, Ludwigshafen, Germany) with a thickening agent added (Hydroxyethyl Cellulose, Cellulosize ${ }^{\circledR} 100$ CG FF, Dow, Midland, USA) was incorporated into the ceramic suspension resulting in the liquid ceramic foam. The compositions were distinguished by the type and content of the mineralizing additives used, which could be $\mathrm{ZnO}$ (PA, $\mathrm{D}_{50}=0.8 \mu \mathrm{m}$, Synth, Diadema, Brazil), $\mathrm{SiO}_{2}$ (Microsilica ${ }^{\circledR} 971-\mathrm{U}$, average particle size of $0.15 \mu \mathrm{m}$, specific surface area of $20 \mathrm{~m}^{2} \mathrm{~g}^{-1}$, Elkem, Oslo, Norway) or $\mathrm{TiO}_{2}$ (Aeroxide ${ }^{\circledR}$ P90, average primary particle size of $14 \mathrm{~nm}$, specific surface area of $90 \mathrm{~m}^{2} \mathrm{~g}^{-1}$, Evonik, Essen, Germany) in contents in the range of $0.6 \mathrm{~mol} \%$ to $2.8 \mathrm{~mol} \%$ of the metallic ion in relation to the $\mathrm{CA}_{6}$ expected to be formed (see Table 2 for weight content). These additives were incorporated into the alumina suspension before adding the organic foam, providing a better homogenization.

Table 1: Basic composition for the ceramic foam

\begin{tabular}{|c|l|c|}
\hline \multicolumn{3}{|c|}{ Ceramic foam composition } \\
\hline \multirow{2}{*}{ Raw material } & wt\% \\
\hline \multirow{4}{*}{$\begin{array}{c}\text { Al2O3-based } \\
\text { Suspension }\end{array}$} & CL370 & 66.03 \\
\cline { 2 - 3 } & A1000SG & 4.97 \\
\cline { 2 - 3 } & Calcium carbonate & 11.20 \\
\cline { 2 - 3 } & Secar 71 & 0.90 \\
\cline { 2 - 3 } & FS60 & 0.083 \\
\cline { 2 - 3 } & Lutensol AT50 & 0.092 \\
\cline { 2 - 3 } & Distilled water & 13.71 \\
\hline \multirow{2}{*}{ Foam } & Vinapor GYP 2680 & 3.01 \\
\cline { 2 - 3 } & Cellulosize 100 CG FF & 0.005 \\
\hline
\end{tabular}


Table 2: Mineralizing agent content in wt $\%$ considering the solid fraction of the ceramic suspension.

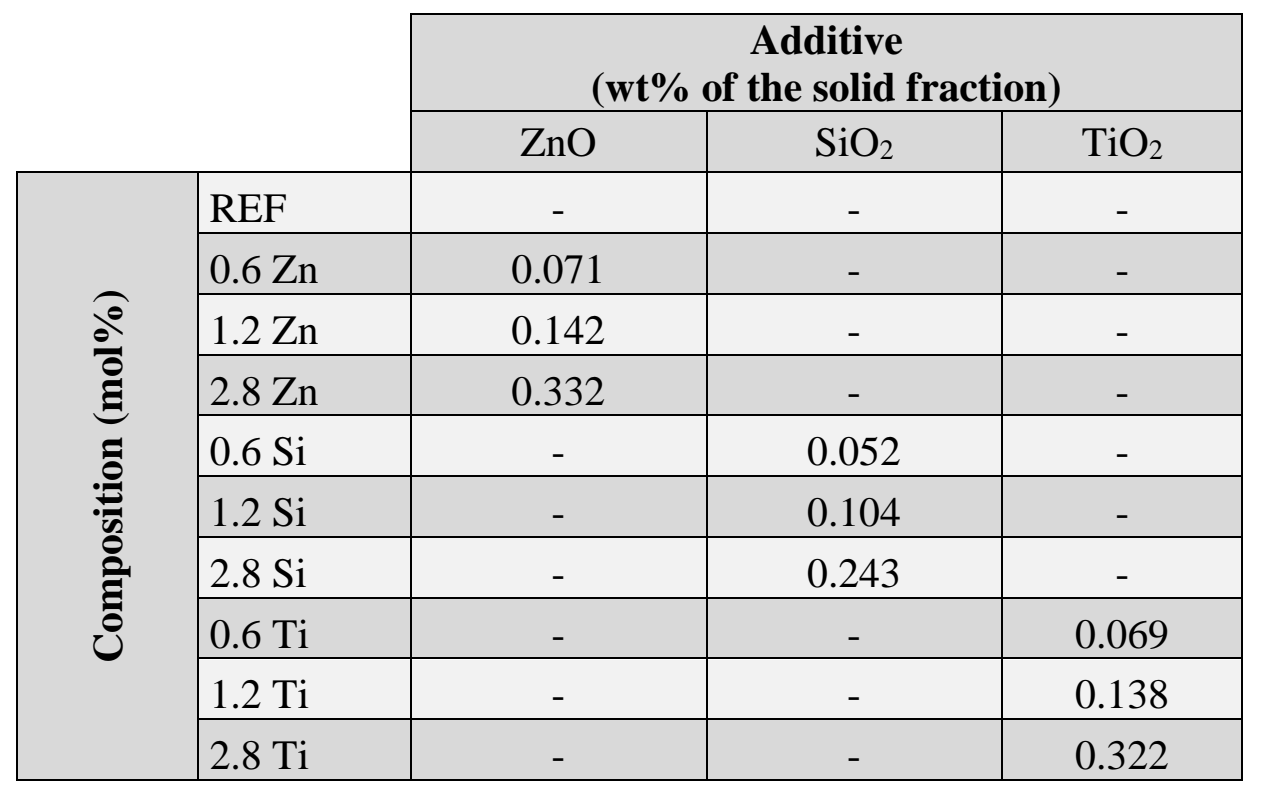

The liquid ceramic foam was moulded into cylinders $(50 \mathrm{~mm} \times 50 \mathrm{~mm})$ and bricks (230mm x $114 \mathrm{~mm} \times 64 \mathrm{~mm})$. All compositions were cured in a climatic chamber (VC 2020, Vötsch, Giessen, Germany) at $50{ }^{\circ} \mathrm{C}$ and a relative humidity of $80 \%$ for 24 hours, followed by drying at $110^{\circ} \mathrm{C}$ for another 24 hours. These samples were fired at different conditions, as described in the Methods section.

\subsection{Methods}

Aiming at predicting the effect of each mineralizing agent on the refractoriness of the materials, thermodynamic simulations were carried out using FactSage ${ }^{\circledR}$ software (Version 6.4, CRCT, Montreal, Canada) to track the phases attained at the thermodynamic equilibrium for each composition. To do this, FToxid database and Equilib module were selected, setting the pressure parameter at 1 atm and varying the temperature up to 1600 ${ }^{\circ} \mathrm{C}$. The data used to quantify the content of $\mathrm{SiO}_{2}, \mathrm{Na}_{2} \mathrm{O}, \mathrm{K}_{2} \mathrm{O}$, and $\mathrm{Fe}_{2} \mathrm{O}_{3}$ present as 
impurities in the raw materials were supplied by the producers. Thus, the temperature was determined at which the liquid phase is firstly generated and its content as a function of the temperature for all compositions described in Section 2.1, considering that the systems attained the thermodynamic equilibrium. Additionally, the aforementioned compositions were fired at $1600{ }^{\circ} \mathrm{C}$ for $5 \mathrm{~h}$ and their refractoriness under load (RUL) was evaluated following the standard ISO 1893 and using RUL/CIC 421 equipment (Netzsch, Selb, Germany). The applied load was set at $0.2 \mathrm{MPa}$ multiplied by the solid volumetric fraction of the tested sample, which resulted in a value close to $0.04 \mathrm{MPa}$. The test was conducted up to $1600^{\circ} \mathrm{C}$ with a heating rate of $5^{\circ} \mathrm{C} \mathrm{min}^{-1}$.

Quantitative mineralogical phase analysis was carried out for each composition after firing from $1200{ }^{\circ} \mathrm{C}$ to $1600^{\circ} \mathrm{C}$, every 100 degrees, always for $5 \mathrm{~h}$. The fired samples were ground and analysed by X-ray diffraction (Geiger-Flex diffraction, Rigaku, Japan) in the $4^{\circ}$ to $90^{\circ}$ range, with a $0.02^{\circ}$ step and using copper $\mathrm{K} \alpha$ radiation and nickel filter. The Rietveld refinements were carried out using the Topas ${ }^{\circledR}$ software (version 4.2, Bruker, Billerica, USA) and the American Mineralogist Crystal Structure Database (AMCSD), ensuring Goodness of Fit $(\mathrm{GOF})<1.5$ and the weighted profile R-factor $(\mathrm{RWP})<15 \%$.

Eight pre-fired $\left(1600{ }^{\circ} \mathrm{C}\right.$ for $\left.5 \mathrm{~h}\right)$ cylinders $(50 \mathrm{~mm} \times 50 \mathrm{~mm})$ of each composition had their linear shrinkage after firing measured, total porosity applying a relationship between the porous sample density (liquid immersion method using water, according to ASTM C20 [8], see Eq. 1) and the density of the solid fraction evaluated by helium pycnometry (AccuPyc 1330, Micromeritics, Atlanta, USA) - see Eq. 2 -, and their cold 
crushing strength evaluation was carried out in MTS 810 equipment (MTS, Eden Prairie, USA) according to ASTM C133 [9].

$$
\begin{aligned}
& d_{\text {porous sample }}=\frac{m_{S}}{\left(m_{U}-m_{I}\right)} \times d_{\text {water }} \\
& P_{T}=\left(1-\frac{d_{\text {porous sample }}}{d_{\text {dense powder }}}\right) \times 100 \%
\end{aligned}
$$

Where $d_{\text {porous sample }}$ is the density of the macroporous sample $\left(\mathrm{g} \mathrm{cm}^{-3}\right) . m_{S}, m_{U}, m_{I}$ their dry, wet and immerse mass $(\mathrm{g})$ respectively, $d_{\text {water }}$, the water density at room conditions $\left(\mathrm{g} \mathrm{cm}^{-3}\right), d_{\text {dense powder }}$, the density of the solid fraction from the sample $\left(\mathrm{g} \mathrm{cm}^{-}\right.$ ${ }^{3}$ ), and $P_{T}$, the total porosity of the macroporous sample (\%).

Additionally, microstructure analysis by scanning electron microscopy (SEM) using the backscattered electron mode (BSE) was accomplished in a XL-30 FEG microscope (Philips, Amsterdam, Netherlands) with energy dispersive X-ray spectroscope (EDS) coupled. The thermal conductivity up to $1200{ }^{\circ} \mathrm{C}$ was evaluated by the parallel hot wire technique using bricks $(230 \mathrm{~mm} \times 114 \mathrm{~mm} \times 64 \mathrm{~mm})$ in TCT 426 equipment (Netzsch, Selb, Germany) according to ASTM C1113 [10].

\section{Results and discussion}

The literature reports promising results about using $\mathrm{MA}$ in $\mathrm{Al}_{2} \mathrm{O}_{3}-\mathrm{CaO}$ systems, such as the decrease in the $\mathrm{CA}_{6}$ formation temperature and its higher aspect ratio growth $[7,11,12]$. However, these MA are, in general, transition metal oxides, which can react 
forming a liquid phase at intermediate temperatures (between $1000{ }^{\circ} \mathrm{C}$ and $1500{ }^{\circ} \mathrm{C}$ ), impairing the material's refractoriness.

A way to foresee the impact on materials refractoriness using MA is to simulate the percentage of the liquid phase that would be formed at the thermodynamic equilibrium for different temperatures, varying the type and content of these additives. FactSage ${ }^{\circledR}$, a piece of software for thermodynamics simulation, was used to estimate the phases formed up to $1800{ }^{\circ} \mathrm{C}$ in the $\mathrm{REF}$ system when adding $\mathrm{SiO}_{2}, \mathrm{ZnO}$ and $\mathrm{TiO}_{2}$ in contents ranging from $0.6 \mathrm{~mol} \%$ to $2.8 \mathrm{~mol} \%$, as shown in Figure 1. These additives were selected based on the literature $[7,12,13]$ because: (i) they have presented some promising results; (ii) have low or no toxicity; and (iii) are easily available.

Analysing these results, it can be seen that all compositions showed liquid phase formation. However, composition REF showed the lowest liquid phase content, followed by compositions with $\mathrm{ZnO}$ additions. According to the thermodynamic simulation, for $\mathrm{ZnO}$-containing compositions, part of the added zinc oxide would react with alumina to form a zinc aluminate $\left(\mathrm{ZnAl}_{2} \mathrm{O}_{4}\right)$ called gahnite, which presents a high melting point (> $1900{ }^{\circ} \mathrm{C}$ ) [14]. For $\mathrm{TiO}_{2}$ - and $\mathrm{SiO}_{2}$-containing compositions, the main liquid phase formation occurred at $1500{ }^{\circ} \mathrm{C}$ and $1275^{\circ} \mathrm{C}$, respectively, whereas for $\mathrm{ZnO}$-containing ones it happened close to $1550{ }^{\circ} \mathrm{C}$. The increase in the MA content did not change the temperature of the main liquid phase formation but increased its amount. Thus, the liquid formed at $1600{ }^{\circ} \mathrm{C}$ for $\mathrm{ZnO}$-containing compositions varied from $0.36 \mathrm{wt} \%$ to $0.60 \mathrm{wt} \%$, for $\mathrm{TiO}_{2}$-containing was in the range between $0.67 \mathrm{wt} \%$ and $1.22 \mathrm{wt} \%$, and for $\mathrm{SiO}_{2}$ containing compositions, from $0.69 \mathrm{wt} \%$ to $1.45 \mathrm{wt} \%$.

Therefore, according to the thermodynamic perspective, adding $\mathrm{SiO}_{2}$ would result in a liquid phase formation at a lower temperature $\left(1275^{\circ} \mathrm{C}\right)$ and at a higher content, 
pointing out its higher potential of reducing the insulators' refractoriness. Accordingly, titanium oxide would be the second to impact this property, whereas zinc oxide should have little effect on it.

Figure 1

It is worth noticing that these results were obtained by thermodynamic simulation, which assumes that the whole system is homogeneous and at equilibrium conditions, additionally, not all likely minor impurities in the raw materials might have been considered (just $\mathrm{SiO}_{2}, \mathrm{Na}_{2} \mathrm{O}, \mathrm{K}_{2} \mathrm{O}$, and $\mathrm{Fe}_{2} \mathrm{O}_{3}$ ). Therefore, samples pre-fired at $1600{ }^{\circ} \mathrm{C}$ for $5 \mathrm{~h}$ were also analysed for their refractoriness under load (RUL) to (i) validate the simulated results, and (ii) evaluate the actual systems out of equilibrium conditions. The obtained results are presented in Figure 2. The profiles are related to the refractoriness of the samples, thus the higher the temperature in which shrinkage starts, the more refractory the material is.

Figure 2

As expected, $\mathrm{SiO}_{2}$-containing compositions showed the lower refractoriness, followed by compositions containing $\mathrm{TiO}_{2}$ and $\mathrm{ZnO}$. As predicted by the thermodynamic simulation, RUL data from ZnO-containing compositions and the REF one did not present significant changes. Additionally, it was seen that increasing the MA content resulted in a decrease of refractoriness for all compositions (also forecast by the thermodynamic simulation), which can be better observed by analysing the $\mathrm{T}_{0.5}$ values, presented in Table 3 . This value $\left(\mathrm{T}_{0.5}\right)$ is defined as the temperature at which shrinkage of $0.5 \%$ is observed after the sample achieved its maximum linear expansion and can be considered as the material softening temperature. 
Table 3: $\mathrm{T}_{0.5}$ values obtained by RUL analysis of compositions containing $\mathrm{SiO}_{2}, \mathrm{TiO}_{2}$, and $\mathrm{ZnO}$.

\begin{tabular}{|c|c|c|}
\hline MA content & MA oxide & $\mathbf{T}_{0.5}\left({ }^{\circ} \mathrm{C}\right)$ \\
\hline \multirow{3}{*}{$0.6 \mathrm{~mol} \%$} & $\mathrm{SiO}_{2}$ & 1460 \\
\hline & $\mathrm{TiO}_{2}$ & $>1600$ \\
\hline & $\mathrm{ZnO}$ & $>1600$ \\
\hline \multirow{3}{*}{$1.2 \mathrm{~mol} \%$} & $\mathrm{SiO}_{2}$ & 1380 \\
\hline & $\mathrm{TiO}_{2}$ & 1590 \\
\hline & $\mathrm{ZnO}$ & $>1600$ \\
\hline \multirow{3}{*}{$2.8 \mathrm{~mol} \%$} & $\mathrm{SiO}_{2}$ & 1220 \\
\hline & $\mathrm{TiO}_{2}$ & 1515 \\
\hline & $\mathrm{ZnO}$ & $>1600$ \\
\hline
\end{tabular}

Data presented in Table 3 once again show the remarkable refractoriness reduction induced by $\mathrm{SiO}_{2}$, even at a low content - see composition $0.6 \mathrm{Si}$, which presented $\mathrm{T}_{0.5}=$ $1460{ }^{\circ} \mathrm{C}$. However, the most relevant conclusion of this analysis is that, based on the structural integrity, all compositions containing $\mathrm{ZnO}$ and $\mathrm{TiO}_{2}$, but $2.8 \mathrm{Ti}$, could be used as a refractory material up to $\sim 1600{ }^{\circ} \mathrm{C}$. This is of great interest as this work aims to obtain insulating materials to be used at high temperatures. Additionally, another point that should be highlighted is the proximity between the results obtained by the thermodynamic simulation and those measured experimentally by RUL.

After analysing the data resulted by adding the mineralizing agents $\mathrm{ZnO}, \mathrm{SiO}_{2}$, and $\mathrm{TiO}_{2}$ on the refractoriness, quantitative mineralogical characterization was carried 
out for each composition using Rietveld refinement in X-ray diffractograms. Figure 3 shows the fraction of calcium hexaluminate $\left(\mathrm{CA}_{6}\right)$ formed in the compositions containing (a) $\mathrm{SiO}_{2}$, (c) $\mathrm{TiO}_{2}$, (e) $\mathrm{ZnO}$, and the diffractograms of compositions (b) $2.8 \mathrm{Si}$, (d) $2.8 \mathrm{Ti}$, (f) $2.8 \mathrm{Zn}$, displayed as a function of the firing temperature. The same analysis was made for composition REF to enable comparisons. It is also worth noting that these characterizations were not made in situ, thus each sample was pre-fired at the mentioned temperature for $5 \mathrm{~h}$ and then analysed by X-ray diffraction.

Figure 3

After the thermal treatment at $1600{ }^{\circ} \mathrm{C}$ for $5 \mathrm{~h}$, all compositions underwent full $\mathrm{CA}_{6}$ formation $(\sim 100 \mathrm{wt} \%)$. On the other hand, firing at $1200{ }^{\circ} \mathrm{C}$ for $5 \mathrm{~h}$ was not enough to generate $\mathrm{CA}_{6}$ in the compositions tested. However, at $1300{ }^{\circ} \mathrm{C}$ for $\mathrm{TiO}_{2}$-containing compositions and $1400^{\circ} \mathrm{C}$ for those containing $\mathrm{ZnO}$, more $\mathrm{CA}_{6}$ was formed compared to composition REF, showing the mineralizing effect of these two additives. Using $\mathrm{SiO}_{2}$ in the evaluated systems does not seem to significantly affect the formation of $\mathrm{CA}_{6}$ at lower temperatures. Additionally, the increase in $\mathrm{ZnO}$ or $\mathrm{TiO}_{2}$ content resulted in a higher fraction of $\mathrm{CA}_{6}$ formed at a lower temperature $\left(1400{ }^{\circ} \mathrm{C}\right.$ and $1300{ }^{\circ} \mathrm{C}$, respectively).

These results are in agreement with those presented by Cinibulk [7]. Studying the formation of $\mathrm{CA}_{6}$ from aluminium and calcium citrates, both produced by the Pechini method, the author observed that the addition of $\mathrm{Zn}^{2+}$ ions induced a higher $\mathrm{CA}_{6}$ formation than the $\mathrm{Si}^{4+}$ ones, for the same content. However, in the systems analysed in that work, the presence of $\mathrm{Ti}^{4+}$ did not affect $\mathrm{CA}_{6}$ formation significantly, which is not in tune with the results presented here. The mineralising effect induced by $\mathrm{TiO}_{2}$ in $\mathrm{CA}_{6}$ formation was 
also observed in alumina castables containing calcium aluminate cement as $\mathrm{Ca}^{2+}$ source, a system much closer to the one studied in this work, by Yuan et al. [15].

Additionally, for compositions $2.8 \mathrm{Zn}$ and $2.8 \mathrm{Ti}$, there was no clear difference between the $\mathrm{CA}_{6}$ content after firing at $1400{ }^{\circ} \mathrm{C}$ and $1600{ }^{\circ} \mathrm{C}$. Thus, a lower firing temperature could be applied to these compositions without decreasing $\mathrm{CA}_{6}$ formation, leading to reductions in energy cost, production time and gas emissions during the manufacturing of components made with these compositions. It is worth mentioning the lower strengthening temperature induced by adding $\mathrm{CaCO}_{3}$ (better discussed in [5] and [6]). Therefore, the mechanical strength should not be greatly affected if these compositions were thermally treated up to $1400^{\circ} \mathrm{C}$ for $5 \mathrm{~h}$.

To better understand the effects of these mineralizing agents on the refractory system, some key physical properties for thermal insulators were evaluated for each composition for samples fired at $1600^{\circ} \mathrm{C}$ for $5 \mathrm{~h}$ : total porosity (Figure 4), linear shrinkage (Figure 5), and cold crushing strength (Figure 6).

Figure 4

By analysing the total porosity data presented in Figure 4, it can be observed that the addition of $0.6 \mathrm{~mol} \%$ of all MA tested induced a total porosity increase (compared to composition REF). However, for higher MA concentrations an opposite effect was seen. This behaviour can be attributed to the formation of a liquid phase during the sintering process, which was expected and foreseen by the thermodynamic simulation (Figure 1). Thus, adding $0.6 \mathrm{~mol} \%$ of MA, the small amount of liquid phase may lead to $\mathrm{CA}_{6}$ formation with a higher aspect ratio (as widely reported in the literature [11-13,16-18]), which increases the volume of pores during $\mathrm{CA}_{6}$ growth due to its poor packing. 
Nevertheless, higher MA concentration would lead to a higher liquid phase amount partially closing pores during sintering [19-21]. Therefore, up to $0.6 \mathrm{~mol} \%$, the share of pore generation due to the asymmetric growth of $\mathrm{CA}_{6}$ overlapped the pore reduction induced by the liquid phase. However, for $1.2 \mathrm{~mol} \%$ and $2.8 \mathrm{~mol} \%$, this scenario was reversed and the effect of the liquid phase on the porosity started to overcome the pore formation due to the anisotropic growth of $\mathrm{CA}_{6}$. Although the increase in MA content resulted in a porosity reduction, all compositions shown in Figure 4 presented total porosity above $80 \%$, which is a suitable value for a macroporous thermal insulator.

By evaluating the linear shrinkage after thermal treatment at $1600{ }^{\circ} \mathrm{C}$ for $5 \mathrm{~h}$ (Figure 5), it can be seen that the increase of $\mathrm{SiO}_{2}$-content induced higher shrinkage in an almost linear trend. This behaviour is consistent with the increase in the liquid-phase content formed in these compositions as it induces a capillarity pressure that results in an attraction force between the ceramic particles during sintering [19-21]. These results are in agreement with those presented by $\mathrm{Li}$ et al. [18], who evaluated the addition of microsilica in macroporous ceramics in the $\mathrm{Al}_{2} \mathrm{O}_{3}-\mathrm{CaO}$ system.

Figure 5

For $\mathrm{ZnO}$-containing compositions, it could be pointed out that increments of zinc oxide amount resulted in lower expansion after firing $\left(1600{ }^{\circ} \mathrm{C}\right.$ for $\left.5 \mathrm{~h}\right)$, which occurred even for the lowest content added $(0.6 \mathrm{~mol} \%)$. This behaviour is also in agreement with those expected in Figure 1 and that described for $\mathrm{SiO}_{2}$-containing compositions.

Compositions containing small amounts of $\mathrm{TiO}_{2}(0.6 \mathrm{~mol} \%$ and $1.2 \mathrm{~mol} \%)$ showed a slight change in their linear shrinkage, which reached values of $-1.0 \%$ and $0.94 \%$, respectively. However, if the standard deviation is taken into account, it can be inferred that these values were not statistically different from the shrinkage value of the 
composition REF. For $2.8 \mathrm{Ti}$ one, an increase in the linear shrinkage was observed, reaching $-0.34 \%$. Again, this trend can be assigned to the expected liquid phase formation.

It is worth noticing that for all compositions, but $2.8 \mathrm{Si}$, there was either expansion or no shrinkage after firing at $1600{ }^{\circ} \mathrm{C}$ for $5 \mathrm{~h}$. This result is relevant as it shows the likelihood of using MA and the reduction of the materials shrinkage, which are the objectives of this work.

Regarding cold crushing strength (see Figure 6), the increase of MA content resulted in higher strength for all additives tested. However, the strengthening was greater for $\mathrm{ZnO}$-containing compositions, which presented values ranging from $2.19 \mathrm{MPa}$ to 6.1 $\mathrm{MPa}$ when $\mathrm{ZnO}$ content varied from $0.6 \mathrm{~mol}$ to $2.8 \mathrm{~mol} \%$ and porosity in the range of $83.8 \%$ to $82.5 \%$, respectively. This better mechanical performance could be related to the higher anisotropy of the $\mathrm{CA}_{6}$ formed in these compositions, as asymmetric phases induce strengthening mechanisms, which is macroscopically carried out by higher mechanical strength.

Figure 6

To analyse this hypothesis and evaluate the microstructural features induced by each MA, compositions containing $\mathrm{SiO}_{2}, \mathrm{TiO}_{2}$ and $\mathrm{ZnO}$ were characterized by scanning electron microscopy (SEM) with the backscattered-electron (BSE) mode. The images obtained can be seen in Figure 7, which show the microstructure of compositions (a - b) $2.8 \mathrm{Si}$, (c - d) $2.8 \mathrm{Ti}$ and $(\mathrm{e}-\mathrm{f}) 2.8 \mathrm{Zn}$, after firing at $1600{ }^{\circ} \mathrm{C}$ for 5 hours. It is worth noticing that XRD analysis showed $\mathrm{CA}_{6}$ content higher than $98 \%$ for these samples (see Figure 3), thus almost all structures observed in SEM images are hibonite grains. 
Initially, one can see that all micrographs showed $\mathrm{CA}_{6}$ formed in asymmetric morphology, albeit in a smaller amount for composition $2.8 \mathrm{Si}$. Additionally, $\mathrm{SiO}_{2}$ seems to have acted favouring plate-like $\mathrm{CA}_{6}$ formation at the expense of acicular morphology, a result already reported in the literature [23]. On the other hand, an increase in acicular $\mathrm{CA}_{6}$ content was seen in $2.8 \mathrm{Ti}$ and $2.8 \mathrm{Zn}$, respectively, which supports the hypothesis about the cold crushing strength (see Figure 6). Thus, the greater mechanical strength attained by $\mathrm{ZnO}$-containing compositions, followed by those containing $\mathrm{TiO}_{2}$ and $\mathrm{SiO}_{2}$ can be associated to the $\mathrm{CA}_{6}$ morphology.

For all compositions evaluated by SEM, the EDS analyses showed that just $\mathrm{CA}_{6}$ was found in the microstructure. In other words, a vitreous phase was neither observed in the grain boundaries, and nor was gahnite $\left(\mathrm{ZnAl}_{2} \mathrm{O}_{4}\right)$ found in $2.8 \mathrm{Zn}$ composition. This lack of detecting the aforementioned phases can be assigned to their small content. Analysing Table 2, it can be observed that the MA content varied from $0.243 \mathrm{wt} \%$ to $0.332 \mathrm{wt} \%$ for all compositions tested by SEM.

Additionally, the decomposition of $\mathrm{CaCO}_{3}$, as well as the poor packing of the asymmetric phases resulted in pores with a diameter close to $5 \mu \mathrm{m}$. Thus, these micrometric pores must interact more efficiently with the electromagnetic radiation emitted at temperatures between $1000{ }^{\circ} \mathrm{C}$ and $2000{ }^{\circ} \mathrm{C}$ [24]. This effect raises the possibility of using $\mathrm{CaCO}_{3}$ with distinct particle size distributions to adjust the microporosity created by its decomposition, maximizing interactions with thermal radiation emitted at high temperatures and, thus, obtaining an insulator with lower effective thermal conductivity. 
Finally, keeping in mind that the main purpose of this work is to produce thermal insulator materials to be applied at high temperatures, compositions $2.8 \mathrm{Zn}$ and $2.8 \mathrm{Ti}$ (considered most promising so far) were evaluated by their effective thermal conductivity $\left(\mathrm{k}_{\text {eff }}\right.$ ) as a function of temperature up to $1200{ }^{\circ} \mathrm{C}$. The results obtained are presented in Figure 8, which also shows data of the REF composition, as a reference.

Compositions 2.8 $\mathrm{Ti}$ and 2.8 $\mathrm{Zn}$ showed lower $\mathrm{k}_{\mathrm{eff}}$ than the $\mathrm{REF}$ one for all temperatures analysed. In the range between $50^{\circ} \mathrm{C}$ and $\sim 800{ }^{\circ} \mathrm{C}$, in which conduction is the main heat transfer phenomenon, this behaviour can be assigned to the higher porosity presented in these MA-containing compositions. Recalling the data in Figure 4, compositions $2.8 \mathrm{Ti}$ and $2.8 \mathrm{Zn}$ showed $\sim 83 \%$ of porosity, whereas REF presented 80 $\%$. However, at higher temperatures $\left(>800^{\circ} \mathrm{C}\right)$, in which radiation becomes more relevant than conduction, the lower thermal conductivity of compositions $2.8 \mathrm{Zn}$ and $2.8 \mathrm{Ti}$ can be attributed to the formation of highly asymmetric $\mathrm{CA}_{6}$, which present micrometric pores (as seen in Figure 7) capable of better spreading the thermal radiation emitted at the tested temperatures [24]. Additionally, a likely opacifying effect induced by $\mathrm{TiO}_{2}$ on the thermal radiation emitted at high temperatures may also have favoured $\mathrm{k}_{\text {eff }}$ decrease [25].

Figure 8

Comparing composition $2.8 \mathrm{Ti}$ to $2.8 \mathrm{Zn}$, one can see that up to $800{ }^{\circ} \mathrm{C}$ their $\mathrm{k}_{\mathrm{eff}}$ values are almost the same. In fact, if the standard deviation is taken into account, it can be inferred that they are not statistically different. However, above $800{ }^{\circ} \mathrm{C}$, the $\mathrm{k}_{\text {eff }}$ of composition $2.8 \mathrm{Zn}$ became significantly higher than the thermal conductivity of composition $2.8 \mathrm{Ti}\left(0.59 \mathrm{Wm}^{-1} \mathrm{~K}^{-1}\right.$ and $0.55 \mathrm{Wm}^{-1} \mathrm{~K}^{-1}$ at $1200{ }^{\circ} \mathrm{C}$, respectively).

Although both compositions presented the same porosity, $\mathrm{TiO}_{2}$ (rutile) can act as an opacifier for the infrared radiation emitted above $\sim 800{ }^{\circ} \mathrm{C}$ [25-27]. Thus, while 
conduction was the main heat transfer phenomenon, both compositions showed an equivalent $\mathrm{k}_{\mathrm{eff}}$, however when radiation became more relevant $\left(>800{ }^{\circ} \mathrm{C}\right)$, the $\mathrm{TiO}_{2}$ containing one was more effective in reducing the thermal energy transport.

\section{Conclusions}

The effects of adding distinct mineralizing agents $\left(\mathrm{ZnO}, \mathrm{SiO}_{2}\right.$, and $\left.\mathrm{TiO}_{2}\right)$ in $\mathrm{Al}_{2} \mathrm{O}_{3}$ $\mathrm{CaCO}_{3}$ macroporous insulators produced by a direct foaming method were studied. $\mathrm{SiO}_{2}$ showed a small effect on the $\mathrm{CA}_{6}$ temperature formation, whereas $\mathrm{ZnO}$ and $\mathrm{TiO}_{2}$ favoured $\mathrm{CA}_{6}$ generation at lower temperatures. For higher additive content $(2.8 \mathrm{~mol} \%), \mathrm{TiO}_{2}$ and $\mathrm{ZnO}$ induced full $\mathrm{CA}_{6}$ formation at $1400^{\circ} \mathrm{C}$, instead of $1600^{\circ} \mathrm{C}$. Additionally, these compositions presented highly asymmetric $\mathrm{CA}_{6}$ morphology, which generated micrometric pores due to its poor packing.

Thermodynamic simulations were used to foresee the impact of each additive on materials refractoriness. According to these analyses, $\mathrm{SiO}_{2}$ would induce the higher refractoriness lost followed by $\mathrm{TiO}_{2}$ and $\mathrm{ZnO}$, which should result in liquid phase formation just above $1550^{\circ} \mathrm{C}$. Refractoriness under load (RUL) analyses carried out on fired samples $\left(1600{ }^{\circ} \mathrm{C}\right.$ for $\left.5 \mathrm{~h}\right)$ confirmed this trend. Using RUL data, the $\mathrm{T}_{0.5}$ value of each composition was calculated, showing that the softening temperatures for $2.8 \mathrm{Si}, 2.8$ $\mathrm{Ti}$, and $2.8 \mathrm{Zn}$ were $1220^{\circ} \mathrm{C}, 1515^{\circ} \mathrm{C}$, and $>1600{ }^{\circ} \mathrm{C}$, respectively. Additionally, all compositions, besides $2.8 \mathrm{Si}$, showed high total porosity (> $80 \%$ ), suitable mechanical strength and expansion after firing at $1600{ }^{\circ} \mathrm{C}$ for $5 \mathrm{~h}$.

Finally, compositions $2.8 \mathrm{Zn}$ and $2.8 \mathrm{Ti}$ (considered the most promising so far) were evaluated according to their thermal conductivity (keff) up to $1200{ }^{\circ} \mathrm{C}$. Both showed 
lower $k_{\text {eff }}$ than the REF one for all temperatures tested, which could be assigned to the higher porosity and smaller pores presented by these compositions. Although this keff reduction induced by $\mathrm{TiO}_{2}$ and $\mathrm{ZnO}$ is welcome, the effects caused by these mineralizing agents in other properties, such as the refractoriness, shrinkage after firing, total porosity, and mechanical strength, were considered. An agreement among all these properties was attained and the best composition for a specific application can be selected. Additionally, to properly select a composition, it must be considered that nanometric $\mathrm{TiO}_{2}$ (aerodynamic diameter of $10 \mu \mathrm{m}$ or less) will be classified as category 2 carcinogen in the European Union from 2021.

\section{Acknowledgments}

This study was financed in part by the Coordenação de Aperfeiçoamento de Pessoal de Nível Superior - Brazil (CAPES) - Finance Code 001; by the Conselho Nacional de Desenvolvimento Científico e Tecnológico - Brazil $(\mathrm{CNPq})$ - Process $\mathrm{n}^{\mathrm{o}}$ 130843/2018-0 and by Fundação de Amparo à Pesquisa do Estado de São Paulo - Brazil (FAPESP) - Process $n^{\circ}$ 2018/07745-5. Additionally, the authors are thankful to BASF Construction Solutions GmbH, to RHI-Magnesita, to the Laboratory of Structural Characterization (LCE/DEMa/UFSCar) and to FIRE - International Federation for Refractory Research and Education. 


\section{References}

[1] J.A.J. Gowlett, The discovery of fire by humans: a long and convoluted process, Philos. Trans. R. Soc. B Biol. Sci. 371 (2016) 20150164. doi:10.1098/rstb.2015.0164.

[2] U.S. Energy Information Administration, Energy intensity by GDP and population, Available at Https:/Www.Eia.Gov/International/Data/World/OtherStatistics/Energy-Intensity-by-Gdp-and-Population. (2017).

[3] PWC, World in 2050: The Long View, Available at Https://Www.Pwc.Com/Gx/En/World-2050/Assets/Pwc-the-World-in-2050-FullReport-Feb-2017.Pdf. (2017).

[4] IEA, World Energy Balances, OECD, 2019. https://webstore.iea.org/worldenergy-balances-2019.

[5] O.H. Borges, T. Santos, V.R. Salvini, V.C. Pandolfelli, $\mathrm{Al}_{2} \mathrm{O}_{3}-\mathrm{CaO}$ macroporous ceramics containing hydrocalumite-like phases, Ceram. Int. 46 (2020) 59295936. doi:10.1016/j.ceramint.2019.11.046.

[6] O.H. Borges, T. Santos Junior, R.R.B. Oliveira, V.R. Salvini, V.C. Pandolfelli, Macroporous high-temperature insulators physical properties by in situ $\mathrm{CA}_{6}$ formation: Does the calcium source matter?, J. Eur. Ceram. Soc. 40 (2020) 36793686. doi:10.1016/j.jeurceramsoc.2020.04.001.

[7] M.K. Cinibulk, Effect of precursors and dopants on the synthesis and grain growth of calcium hexaluminate, J. Am. Ceram. Soc. 81 (1998) 3157-3168. doi:10.1111/j.1151-2916.1998.tb02751.x.

[8] ASTM, C20: Standard test methods for apparent porosity, water absorption, apparent specific gravity, and bulk density of burned refractory brick and shapes by boiling water, (2015). doi:10.1520/C0020-00R15.

[9] ASTM, C133: Standard test methods for cold crushing strength and modulus of rupture of refractories, (2015). doi:10.1520/C0133-97R15.

[10] ASTM, C1113: Standard test method for thermal conductivity of refractories by 
hot wire (Platinum Resistance Thermometer Technique), (2019).

doi:10.1520/C1113_C1113M-09R19.

[11] J. Sakihama, R. Salomão, Microstructure development in porous calcium hexaluminate and application as a high-temperature thermal insulator: a critical review, Interceram - Int. Ceram. Rev. 68 (2019) 58-65. doi:10.1007/s42411-0190034-7.

[12] R. Salomão, V.L. Ferreira, I.R. de Oliveira, A.D.V. Souza, W.R. Correr, Mechanism of pore generation in calcium hexaluminate $\left(\mathrm{CA}_{6}\right)$ ceramics formed in situ from calcined alumina and calcium carbonate aggregates, J. Eur. Ceram. Soc. 36 (2016) 4225-4235. doi:10.1016/j.jeurceramsoc.2016.05.026.

[13] C. Domínguez, J. Chevalier, R. Torrecillas, G. Fantozzi, Microstructure development in calcium hexaluminate, J. Eur. Ceram. Soc. 21 (2001) 381-387. doi:10.1016/S0955-2219(00)00143-6.

[14] Fact-Web, FactSage, $\mathrm{Al}_{2} \mathrm{O}_{3}-\mathrm{ZnO}$ phase diagram using FToxide (oxide databases), (2019). http://www.crct.polymtl.ca/fact/phase_diagram.php?file=Al-ZnO_Al2O3-ZnO.jpg\&dir=FToxid.

[15] W. Yuan, H. Tang, H. Shang, J. Li, C. Deng, H. Zhu, Effects of $\mathrm{TiO}_{2}$ addition on kinetics of in situ spinel formation and properties of alumina-magnesia refractory castables, J. Ceram. Sci. Technol. 8 (2017) 121-128. doi:10.4416/JCST201600098 .

[16] F. Wang, X. Li, P. Chen, G.M. Kale, B. Zhu, The adjustment of CA $\mathrm{C}_{6}$ morphology and its effect on the thermo-mechanical properties of high temperature composites, (2018) 977-983.

[17] L. An, H.M. Chan, K.K. Soni, Control of calcium hexaluminate grain morphology in in-situ toughened ceramic composites, J. Mater. Sci. 31 (1996) 3223-3229. doi:10.1007/BF00354672.

[18] Y. Li, R. Xiang, N. Xu, Q. Wang, S. Li, M. Wu, C. Yang, Fabrication of calcium hexaluminate-based porous ceramic with microsilica addition, Int. J. Appl. Ceram. Technol. 15 (2018) 1054-1059. doi:10.1111/ijac.12868. 
[19] W. Kingery, H.K. Bowen, D.R. Uhlmann, Introduction to ceramics, 2nd ed., John Wiley \& Sons, Ltd, New York, NY, 1975.

[20] M.W. Barsoum, Fundamentals of ceramics, IOP, Philadelphia, 1997.

[21] J.S. Reed, Principles of ceramics processing, 2nd ed., Wiley-Interscience, 1995.

[22] H. Bolio-Arceo, F.P. Glasser, Zinc oxide in cement clinkering: part 1. Systems $\mathrm{CaO}-\mathrm{ZnO}-\mathrm{Al}_{2} \mathrm{O}_{3}$ and $\mathrm{CaO}-\mathrm{ZnO}-\mathrm{Fe}_{2} \mathrm{O}_{3}$, Adv. Cem. Res. 10 (1998) 25-32. doi:10.1680/adcr.1998.10.1.25.

[23] J. Khajornboon, K. Ota, K. Washijima, T. Shiono, Control of hexagonal platelike microstructure of $i n$-situ calcium hexaluminate in monolithic refractories, J. Asian Ceram. Soc. 6 (2018) 196-204. doi:10.1080/21870764.2018.1484621.

[24] P.I.B.G.B. Pelissari, R.A. Angélico, V.R. Salvini, D.O. Vivaldini, V.C. Pandolfelli, Analysis and modeling of the pore size effect on the thermal conductivity of alumina foams for high temperature applications, Ceram. Int. 43 (2017) 13356-13363. doi:10.1016/j.ceramint.2017.07.035.

[25] D.O. Vivaldini, A.A.C. Mourão, V.R. Salvini, V.C. Pandolfelli, Review: Fundamentals and materials for the microstructure design of high performance refractory thermal insulating, Cerâmica. 60 (2014) 297-309. doi:10.1590/S036669132014000200021. (in Portuguese).

[26] J. Kuhn, T. Gleissner, M.C. Arduini-Schuster, S. Korder, J. Fricke, Integration of mineral powders into $\mathrm{SiO}_{2}$ aerogels, J. Non. Cryst. Solids. 186 (1995) 291-295. doi:10.1016/0022-3093(95)00067-4.

[27] J. Wang, J. Kuhn, X. Lu, Monolithic silica aerogel insulation doped with $\mathrm{TiO}_{2}$ powder and ceramic fibers, J. Non. Cryst. Solids. 186 (1995) 296-300. doi:10.1016/0022-3093(95)00068-2. 


\section{Figure Captions}

Figure 1: Thermodynamic simulation of the amount of liquid formed as a function of temperature for samples containing distinct mineralizing agent type and content.

Figure 2: Linear dimensional variation as a function of temperature measured during refractoriness under load (RUL) tests for compositions containing distinct contents of $\mathrm{ZnO}, \mathrm{SiO}_{2}, \mathrm{TiO}_{2}$, and for composition REF, with no mineralizing additives added.

Figure 3: Amount of $\mathrm{CA}_{6}$ formed in samples containing (a) $\mathrm{SiO}_{2}$, (c) $\mathrm{TiO}_{2}$ and (e) $\mathrm{ZnO}$, and X-ray profiles of compositions (b) $2.8 \mathrm{Si}$, (d) $2.8 \mathrm{Ti}$ and (f) $2.8 \mathrm{Zn}$, all as a function of the firing temperature. In the diffractograms, $\alpha$-alumina peaks are marked with $\diamond, \mathrm{CA}_{2}$ peaks with $₫$, and $\mathrm{CA}_{6}$ ones with $\bullet$.

Figure 4: Total porosity for compositions containing distinct type and content of mineralizing agents. All samples were fired at $1600{ }^{\circ} \mathrm{C}$ for $5 \mathrm{~h}$.

Figure 5: Linear shrinkage for compositions containing distinct type and content of mineralizing agents. All samples were fired at $1600{ }^{\circ} \mathrm{C}$ for $5 \mathrm{~h}$.

Figure 6: Cold crushing strength for compositions containing distinct type and content of mineralizing agents. All samples were fired at $1600{ }^{\circ} \mathrm{C}$ for $5 \mathrm{~h}$.

Figure 7: SEM images for the microstructure of compositions $(\mathrm{a}-\mathrm{b}) 2.8 \mathrm{Si},(\mathrm{c}-\mathrm{d}) 2.8$ Ti, and (e - f) $2.8 \mathrm{Zn}$. All samples were fired at $1600{ }^{\circ} \mathrm{C}$ for $5 \mathrm{~h}$ and analysed in backscattered-electron (BSE) mode.

Figure 8: Effective thermal conductivity ( $\mathrm{k}_{\mathrm{eff}}$ ) of compositions REF, 2.8 Ti, and $2.8 \mathrm{Zn}$ as a function of temperature up to $1200^{\circ} \mathrm{C}$. 


\section{Figures}

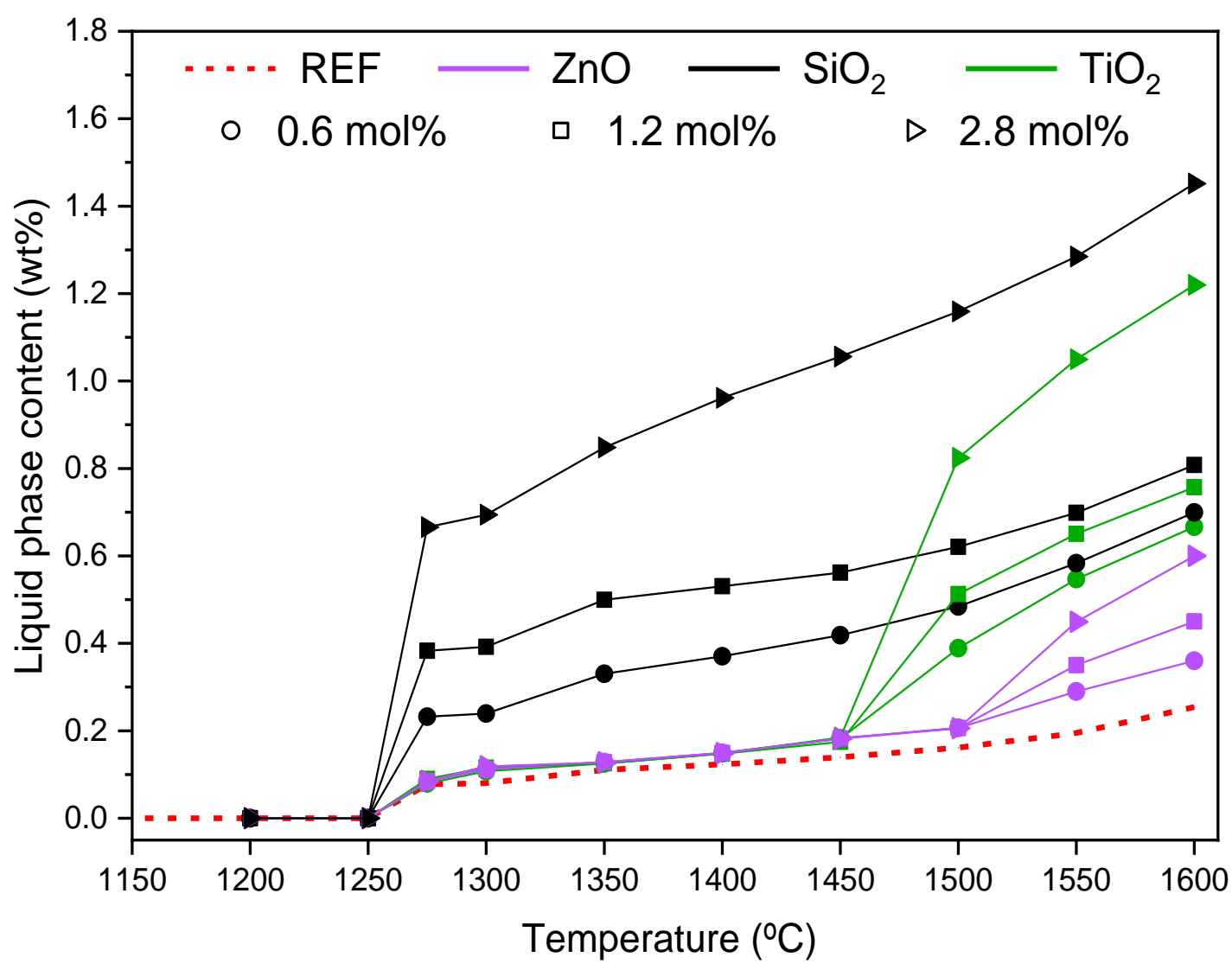

Figure 1: Thermodynamic simulation of the amount of liquid formed as a function of temperature for samples containing distinct mineralizing agent type and content. 


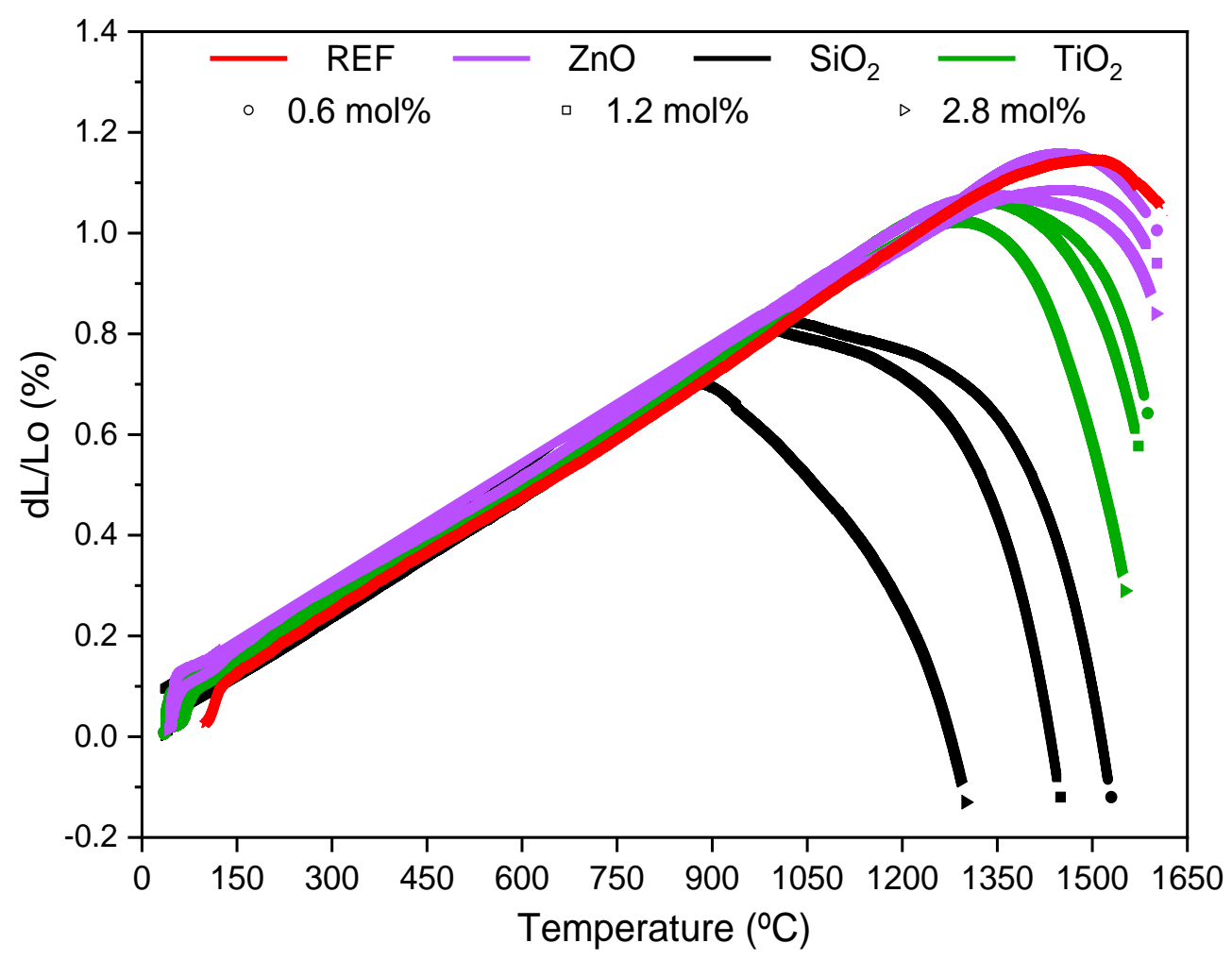

Figure 2: Linear dimensional variation as a function of temperature measured during refractoriness under load (RUL) tests for compositions containing distinct contents of $\mathrm{ZnO}$, $\mathrm{SiO}_{2}, \mathrm{TiO}_{2}$, and for composition REF, with no mineralizing additives added. 

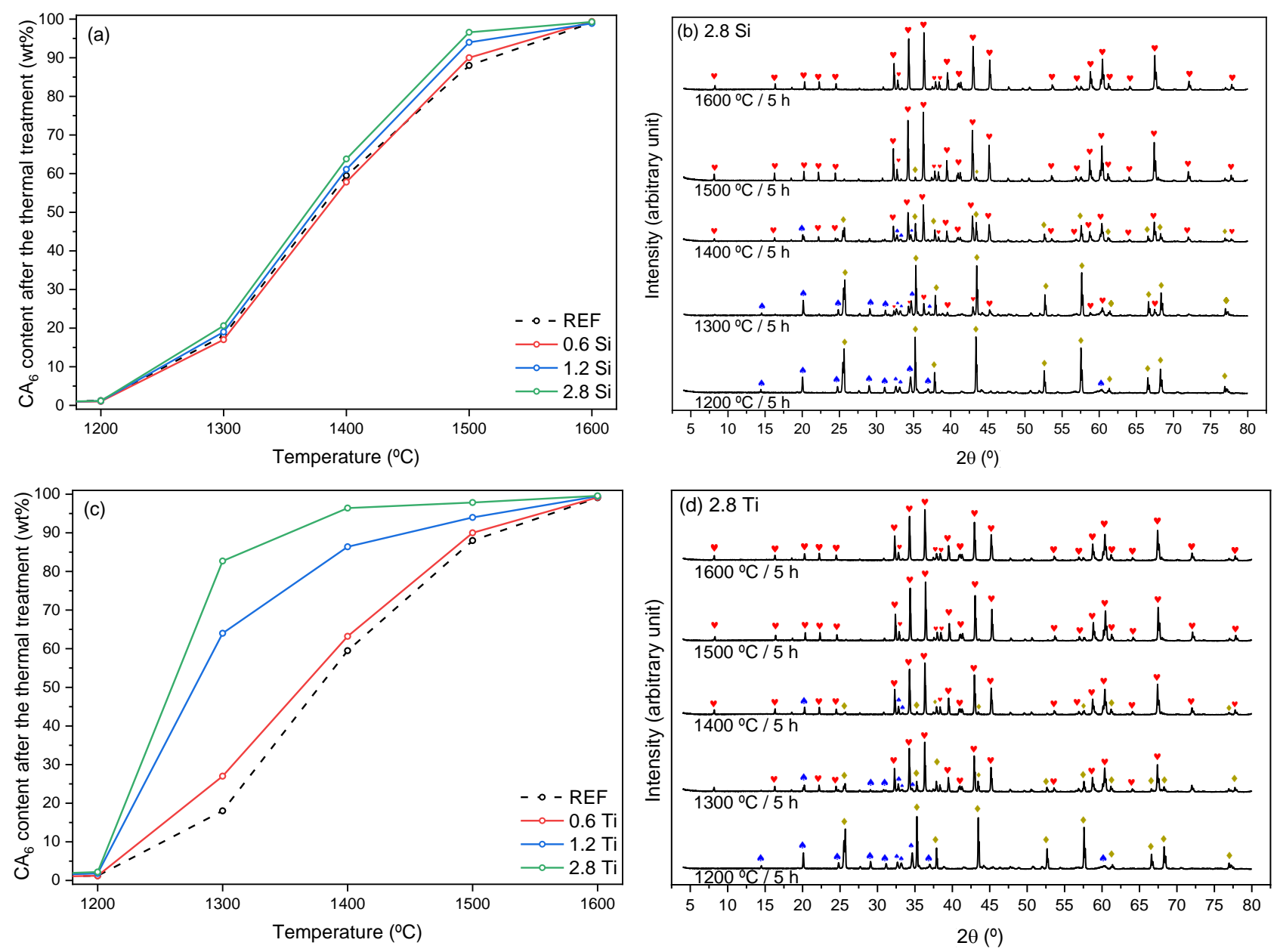

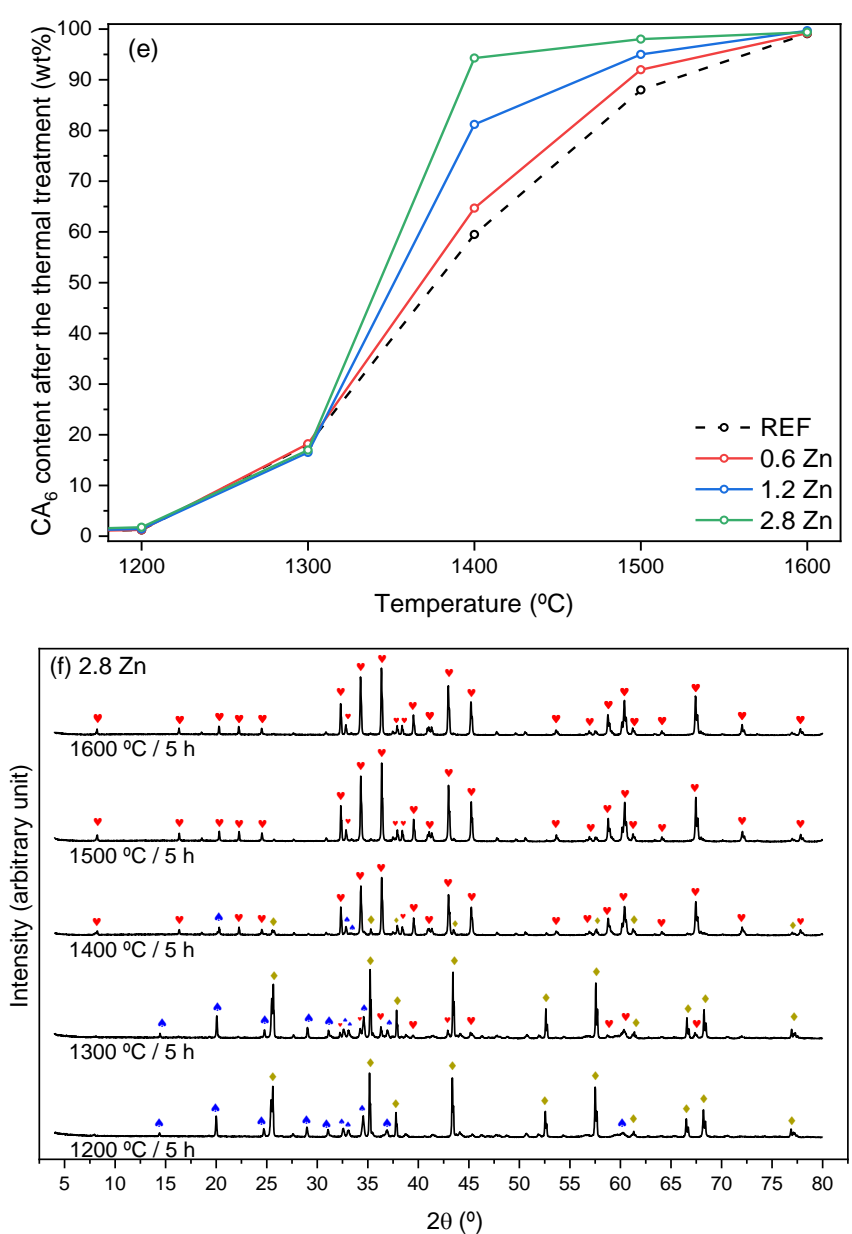

Figure 3: Amount of $\mathrm{CA}_{6}$ formed in samples containing (a) $\mathrm{SiO}_{2}$, (c) $\mathrm{TiO}_{2}$ and (e) $\mathrm{ZnO}$, and Xray profiles of compositions (b) $2.8 \mathrm{Si}$, (d) $2.8 \mathrm{Ti}$ and (f) $2.8 \mathrm{Zn}$, all as a function of the firing temperature. In the diffractograms, $\alpha$-alumina peaks are marked with $\diamond, \mathrm{CA}_{2}$ peaks with $\uparrow$, and $\mathrm{CA}_{6}$ ones with $\bullet$. 


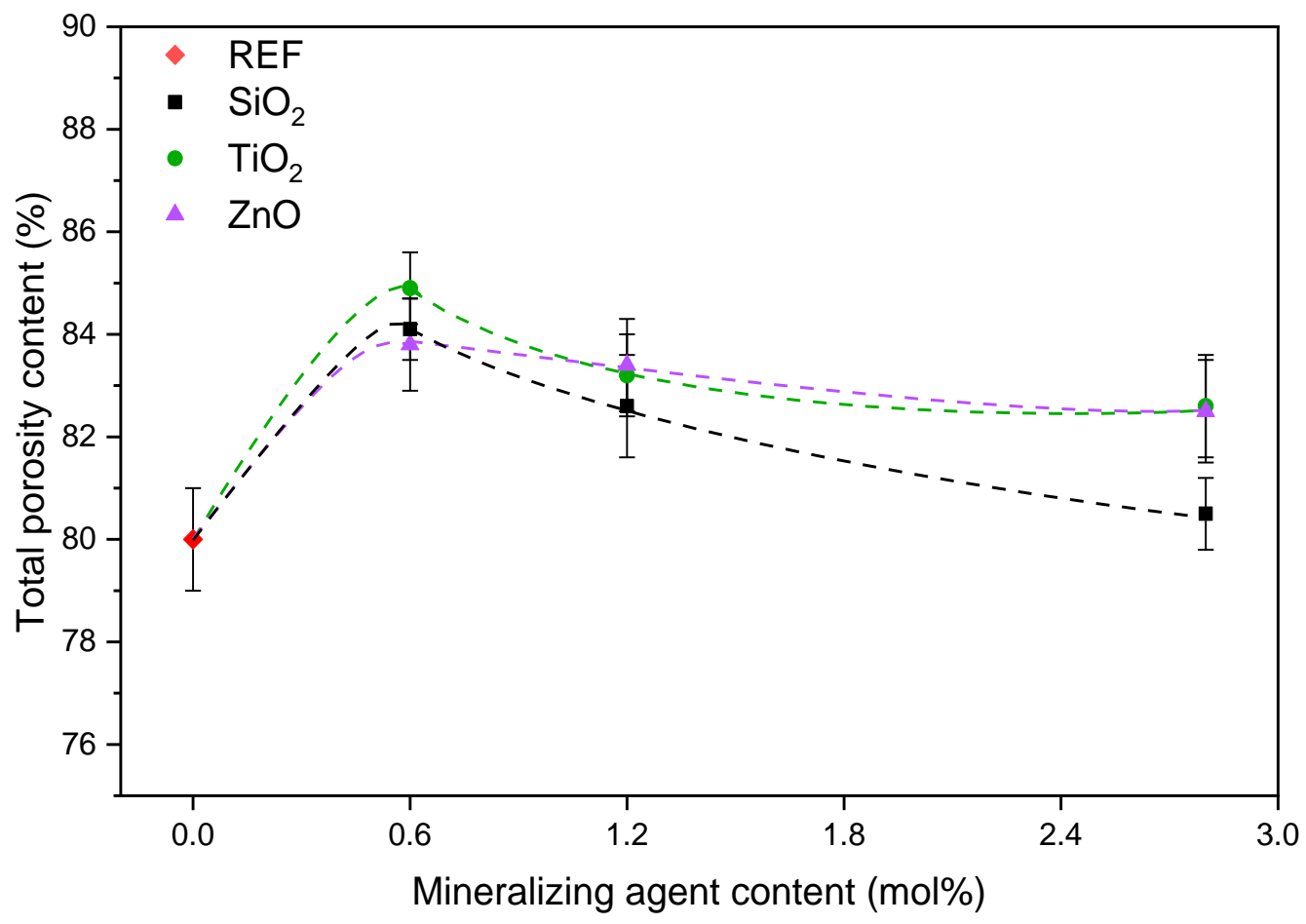

Figure 4: Total porosity for compositions containing distinct type and content of mineralizing agents. All samples were fired at $1600{ }^{\circ} \mathrm{C}$ for $5 \mathrm{~h}$.

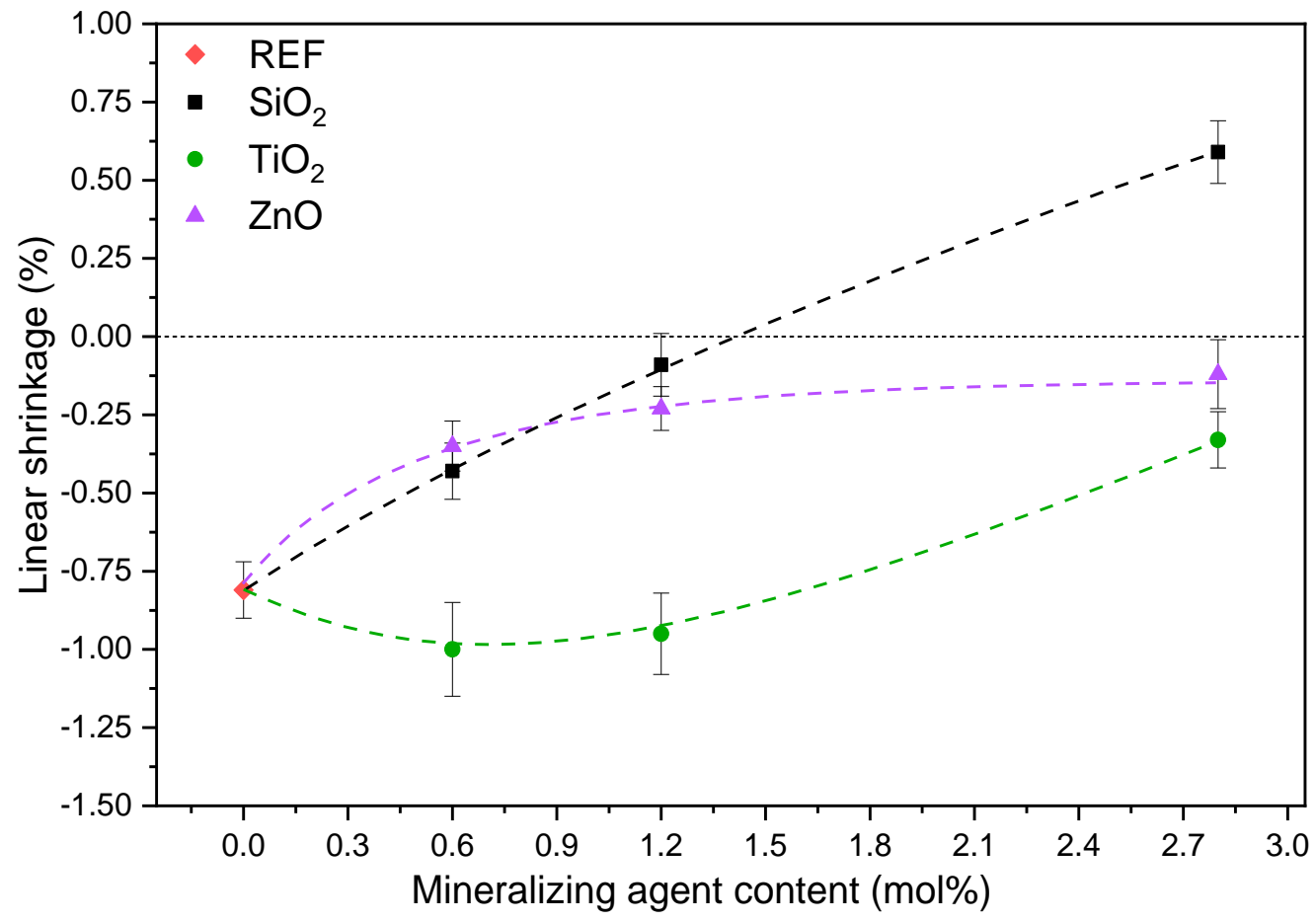

Figure 5: Linear shrinkage for compositions containing distinct type and content of mineralizing agents. All samples were fired at $1600^{\circ} \mathrm{C}$ for $5 \mathrm{~h}$. 


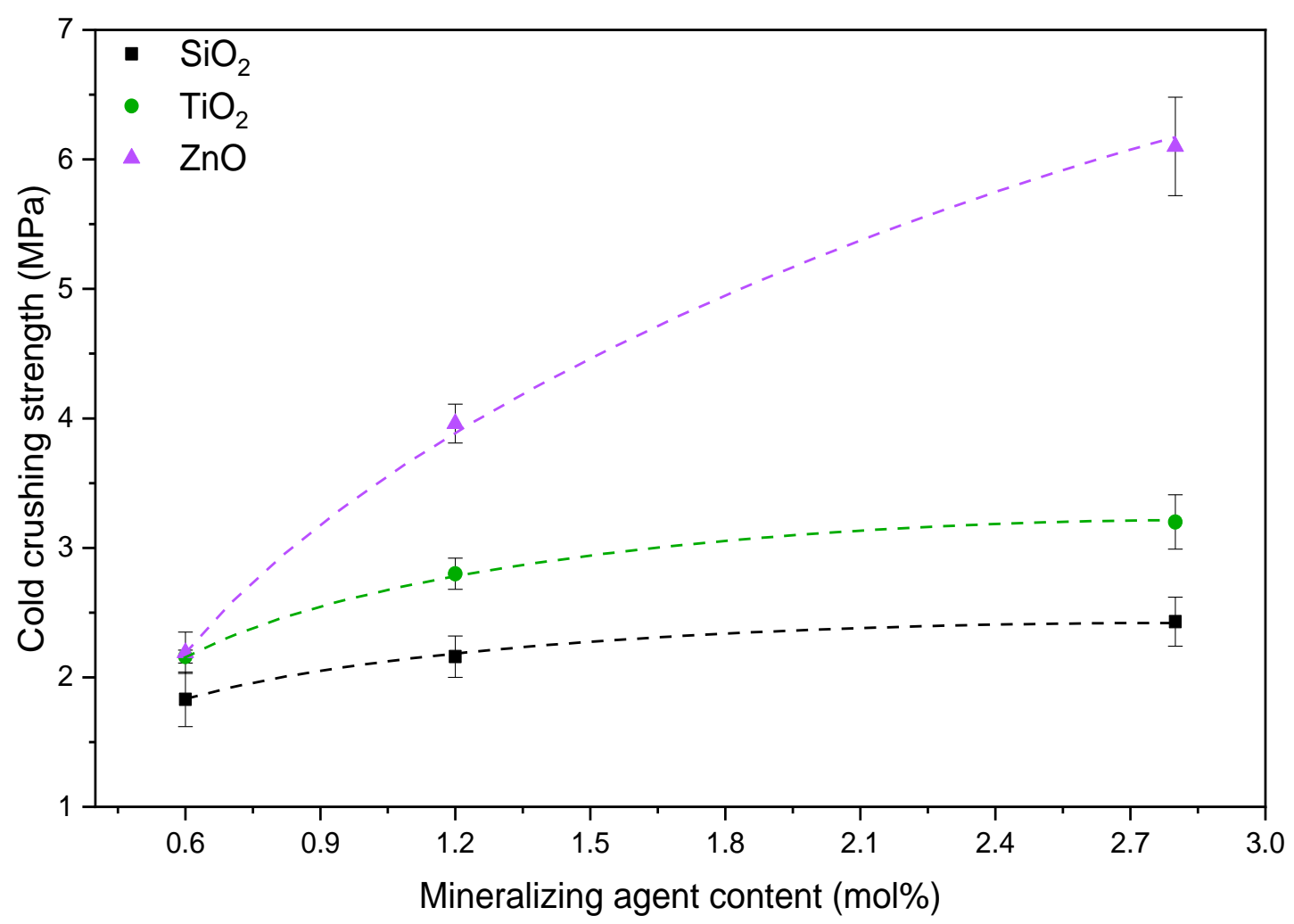

Figure 6: Cold crushing strength for compositions containing distinct type and content of mineralizing agents. All samples were fired at $1600{ }^{\circ} \mathrm{C}$ for $5 \mathrm{~h}$. 

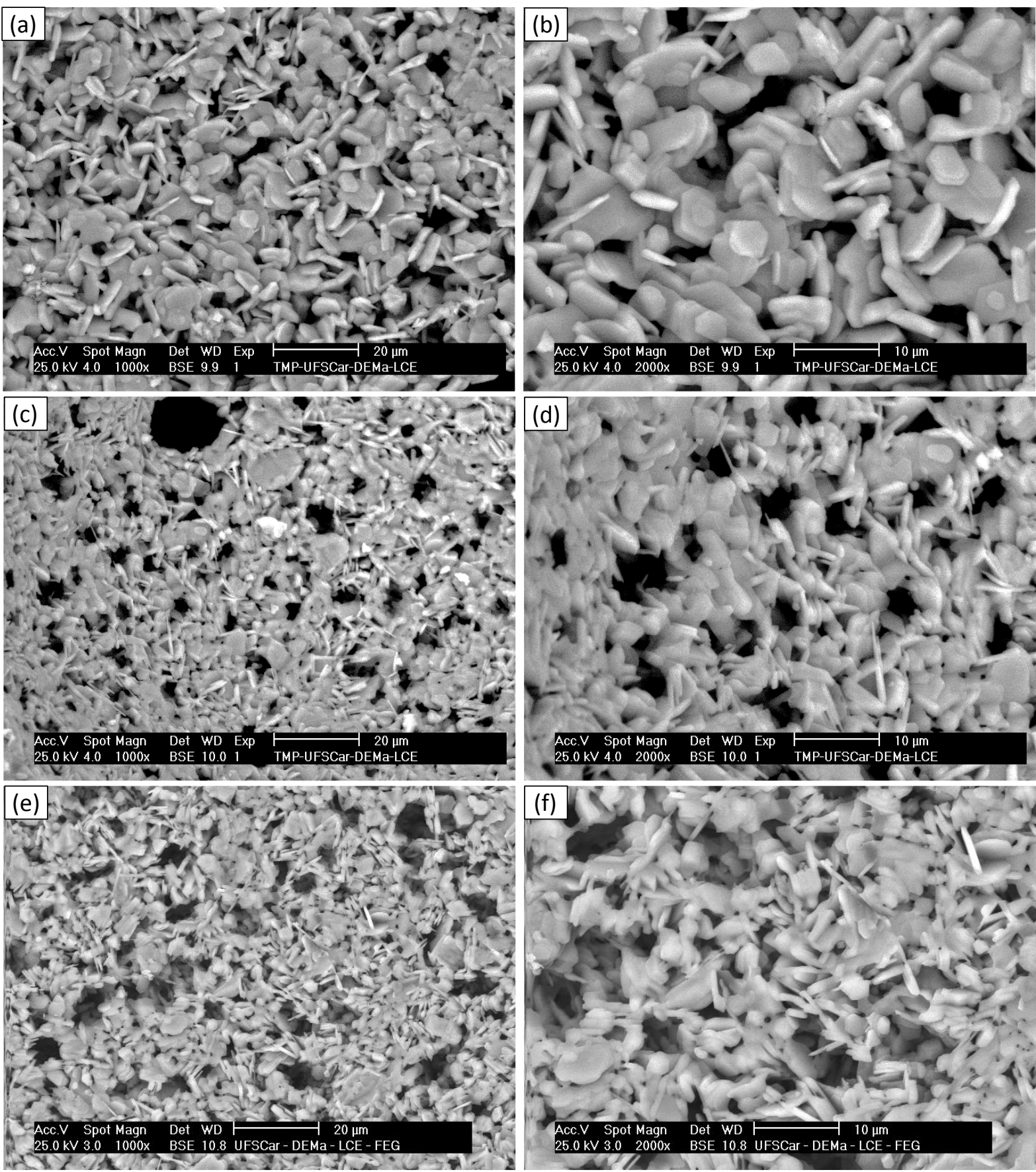

Figure 7: SEM images for the microstructure of compositions (a - b) $2.8 \mathrm{Si}$, (c - d) $2.8 \mathrm{Ti}$, and (e - f) $2.8 \mathrm{Zn}$. All samples were fired at $1600{ }^{\circ} \mathrm{C}$ for $5 \mathrm{~h}$ and analysed in backscattered-electron (BSE) mode. 


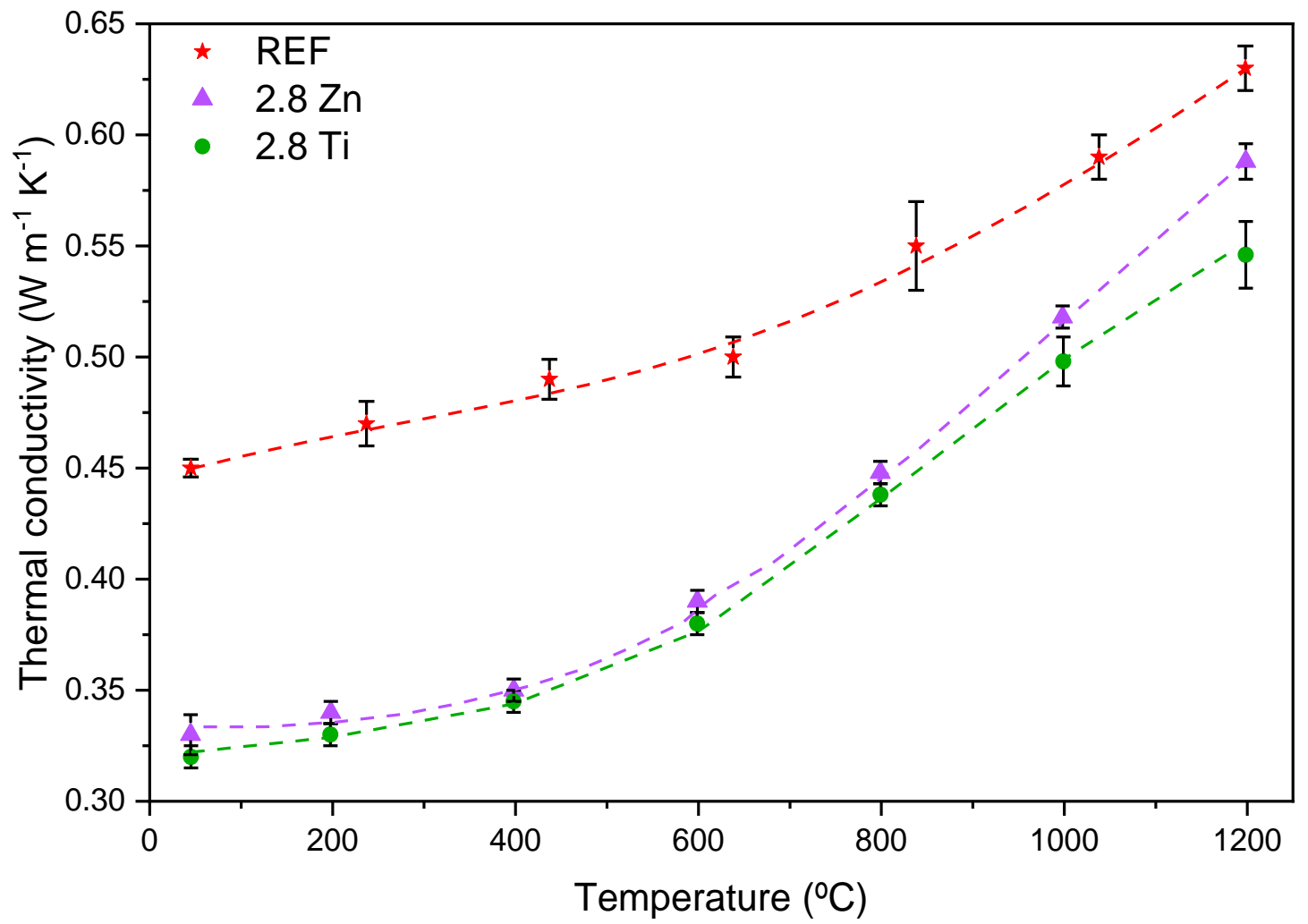

Figure 8: Effective thermal conductivity (keff) of compositions REF, $2.8 \mathrm{Ti}$, and $2.8 \mathrm{Zn}$ as a function of temperature up to $1200^{\circ} \mathrm{C}$. 